\title{
Comparative study of the smooth muscle contractor activity of airborne dusts and of dustiness in cotton, flax, and jute mills
}

\author{
P. J. NICHOLLS and J.W. SKIDMORE \\ Welsh School of Pharmacy, UWIST, Cardiff CF1 3NU and Medical Research Council's \\ Pneumoconiosis Unit, Llandough Hospital, Penarth CF6 1XW, Glamorgan
}

\begin{abstract}
Nicholls, P. J. and Skidmore, J. W. (1975). British Journal of Industrial Medicine, 32, 289-296. Comparative study of the smooth muscle contractor activity of airborne dusts and of dustiness in cotton, flax, and jute mills. A bioassay technique using isolated guinea-pig ileum was employed to compare the smooth muscle contractor activity of various dusts from mills in which the prevalence of byssinosis was known. The activity of dust from a mill spinning a coarse grade of cotton was several times greater than that in dust from a mill processing a fine grade of cotton. There was a similar order in the difference of the prevalence of byssinosis in these mills. However, the activities of fine cotton, flax, and jute dusts were very similar to each other, in spite of marked differences in the prevalence of byssinosis in these mills. For cotton dust, smooth muscle contractor activity was associated with all particle sizes, although the lowest level of activity was found in the largest sized fraction $(<2 \mathrm{~mm})$. Activity in the cotton dust extracts was not correlated with nitrogen, carbohydrate, or potassium content. However, about one-fifth of the activity of a cotton dust extract was associated with an insoluble particulate fraction. The possible chemical nature of the watersoluble contractor agent is discussed. It is concluded that, until the role of this agent in the pathogenesis of byssinosis has been established, the bioassay technique cannot be employed as a means of assessing the byssinogenic potential of cotton dust.
\end{abstract}

Several hypotheses have been advanced concerning the factors which may cause the symptoms of byssinosis and the changes of lung function reported in workers exposed to the dusts of cotton and flax (Schilling, 1956; McKerrow et al., 1958; Bouhuys, Van Duyn, and Van Lennep, 1961; Schilling et al., 1964; Elwood et al., 1965; Elwood, 1965). That the effects are non-specific and are due simply to the dust has been shown to be unlikely by McKerrow et al. (1958). A second hypothesis is that there is a specific substance or group of substances in the dust which causes narrowing of the airway either by direct action on the smooth muscle of the bronchi and bronchioles (Davenport and Paton, 1962; Nicholls, 1962) or through a histamine-release mechanism (Antweiler, 1960; Bouhuys, 1963a, b; Nicholls, Nicholls, and Bouhuys, 1966). A third hypothesis proposes an immunological mechanism (Massoud and Taylor, 1964) but this is not supported by the results of more recent investigations in normal subjects (Edwards et al., 1970). Indeed, the reaction of the so-called byssinosis antigen with immunoglobulins is remarkably non-specific (Edwards and Jones, 1974). It has also been suggested that bacterial endotoxins present in cotton dust could be responsible for the symptoms of byssinosis (Pernis et al., 1961). However, while the role of these bacterial products in the causation of mill fever is generally accepted, their ability to produce byssinosis-like symptoms has been questioned (Antweiler, 1961). A 
more recent study has demonstrated that chronic inhalation of bacterial endotoxin by rabbits causes a hypersensitivity reaction in pulmonary tissue (Cavagna, Foa, and Vigliani, 1969) but the relation of this interesting phenomenon to the symptoms of byssinosis remains to be evaluated. Braun et al. (1973) have demonstrated, in cotton dust, proteolytic enzyme activity probably of fungal origin. These workers proposed that this activity is involved in the production of the signs associated with byssinosis.

It is also possible that these textile dusts of vegetable origin possess other biological actions in addition to those already described and that several mechanisms may operate in combination to produce the symptoms of byssinosis.

Roach and Schilling (1960) observed that the prevalence of byssinosis is much lower in mills processing fine cotton than in those using coarser grades, and that the difference could not be fully explained by differences in the dustiness of the working areas. Nicholls (1962) found that the smooth muscle contractor activity of cotton and flax dusts assayed on the isolated guinea-pig ileum, was greater than that of dusts obtained from jute and sisal mills. As classified byssinosis has not been found among jute mill workers (Mair et al., 1960) although exposure to jute dust may cause a reduction in FEV 1.0 in some individuals (Valić and Žuškin, 1971), it appeared that a comparison of the smooth muscle contractor activity of dusts from various types of mill would be worthwhile. Therefore, dusts were assayed from cotton, flax, and jute mills in which there was already knowledge about the prevalence of byssinosis. It was considered that correlation between smooth muscle contractor activity and the prevalence of byssinosis could possibly indicate (1) the relevance of the contractor activity to the appearance of the symptoms of the disease, and (2) that a bioassay based on this activity might provide a means of assessing the 'byssinogenic' potential of a dust. A study of some chemical differences in the dust was also made in an attempt to determine the chemical nature of the active agent in dust.

\section{Methods}

For the investigation, samples of airborne dust were collected during October 1960 (series A) in the cardrooms of two Lancashire cotton mills, one processing a fine cotton and the other a coarse cotton. The study of Roach and Schilling (1960) showed that the prevalence of byssinosis in carding engine operatives in these two mills was 22 and $63 \%$ respectively. Samples of airborne dusts were also collected during the following January in the cardroom of a flax mill and in the preparation room of a jute mill in Scotland. These were mills included in a study of byssinosis by Mair et al. (1960). These authors found a prevalence of $9 \%$ in the flax mills and none in the jute mills in the sample examined.

After a period of three years (series B) the investigation with the cotton mills was repeated and extended.

\section{Collection of dust samples}

1. For bioassay As a minimum of $1 \mathrm{~g}$ dust was needed for bioassay, domestic vacuum cleaners fitted with filter paper bags were used to collect samples of dust from the air near the carding engines in the cotton and flax mills. In the jute mill the dust concentration in the cardroom was too low for samples to be collected in a reasonable time and therefore samples were obtained near the spreader in the preparation room. The vacuum cleaners were raised $1.2 \mathrm{~m}$ from the floor and sampled for the full working shift, the dust collected containing particles of all sizes. Daily samples were obtained from the Thursday of one week to the Wednesday of the following week.

2. Dust concentrations Simultaneously with the collection of the dust samples for bioassay, dust samples were collected using the Hexhlet/Soxhlet sampling machine to determine the contribution of three size fractions to the total and also to measure the concentration of the dust. The Hexhlet sampler collected, on its filter, dust particles which by virtue of their terminal velocities penetrated an elutriator designed to collect all particles with terminal velocities greater than that of a $7 \cdot 1 \mu \mathrm{m}$ unit density sphere. The Soxhlet, a Hexhlet on which the elutriator was replaced by a wire gauze with $2 \mathrm{~mm}$ apertures, collected on its filter the fraction smaller than about $2 \mathrm{~mm}$ and on the gauze the fraction larger than about $2 \mathrm{~mm}$.

In the repeat investigation in the cotton mills, more sampling machines were used to collect, over a week, sufficient dust in each size fraction to permit bioassay.

\section{Bioassay of smooth muscle contractor activity}

Assay of the activity of the dust samples on the isolated guinea-pig ileum was made with extracts of the dust freshly prepared in Tyrode solution adjusted to $\mathrm{pH} 7 \cdot 4$ (Nicholls, 1962), extracts older than $3 \mathrm{hr}$ being discarded. The assays were performed within six months of the collection of the dust samples. During this time there was no apparent change in the smooth muscle contractor activity of the dusts.

In one instance an aliquot of a freshly prepared extract of dust from the coarse cotton mill was filtered under suction through a cellulose membrane (Millipore) possessing a mean pore diameter of $0.2 \mu \mathrm{m}$. Both the filtered and unfiltered extracts were assayed biologically.

1. Standards of activity In previous work on the level of contractor activity in vegetable fibre dusts (Nicholls, 1962 ), the assessment was made in terms of histamine, that is, the activity of the dust was expressed as that amount of histamine producing the same degree of muscle contraction as that of the extract. However, as histamine is not identical with the contractor substance in cotton and jute dusts (Davenport and Paton, 1962), it seemed more appropriate to assay the activity of the dusts using a standard reference dust for comparison. The dust employed as a standard was obtained from the cardroom of the Dutch mill processing a fine grade of cotton. This dust was collected from the air near the carding engines using domestic vacuum cleaners as described above for 
the other dusts at the same time as series $\mathrm{A}$. The activity of this dust was arbitrarily assigned the value of 400 units of activity/g dust. This was the standard against which the cotton dust samples collected in series A were assayed.

For the assay of the cotton dusts collected in series B, the sample of 'Thursday' dust of series A from the mill spinning the coarse cotton was used as the standard for comparison. This dust contained 3400 units of activity/g as determined by assay with the standard Dutch dust.

During a comparison of the standard Dutch dust with that of flax dust obtained from a New Zealand flax mill in 1960, doubt was cast on the identity of the active contractor agent in these two dusts. It was found on a number of occasions that the sensitivity of the ileum became markedly lowered to the action of the flax while the sensitivity to cotton was unchanged. Accordingly, it was decided to employ this flax dust as the standard for assay of the flax samples. This dust had also been collected in a manner similar to that for the standard cotton dust sample. As flax and jute fibres have a similar anatomical origin, namely, bast fibres, the New Zealand flax dust was also employed as the standard for the assay of the jute dusts. When the activities of the standard Dutch cotton and standard flax dust were compared on guinea-pig ileum preparations that maintained their sensitivity to both materials, it was found that the flax dust was half as potent as the cotton. Therefore the flax dust was assigned the activity of 200 units of activity/g so that the values obtained in the assay of flax and jute dusts would be comparable to some extent with those of the cotton dusts.

Although the use of a separate standard for flax and jute reduces the reliability of the overall comparison of the bioassays, it was considered that the most important aspect of the study was the comparison between dusts from the coarse and fine cotton mills.

2. Procedure The assay was performed on the isolated guinea-pig ileum (Hartley strain) suspended in $5 \mathrm{ml}$ aerated Tyrode solution $\mathrm{pH} 7.4$ containing atropine sulphate and mepyramine maleate (both at $0.01 \mu \mathrm{g} / \mathrm{ml}$ ). Guinea-pig ileum was used as this preparation gave good responses to the unidentified smooth muscle contractor substance of dust extracts (Davenport and Paton, 1962). Atropine was employed to prevent the appearance of occasional spontaneous increases in muscle tone and mepyramine was included to antagonize the effect of the small amounts of histamine present in the dust extracts. Not all guinea-pigs provide muscle preparations that are sensitive to the dust and in the present series only about $60 \%$ of the animals were found to respond to the extracts. The reason for this is unknown. Doses (volumes) of dust extracts were added to the bath at intervals of five minutes and remained in contact with the tissue for 30 seconds. In all cases the volume of fluid bathing the ileum was maintained at $5 \mathrm{ml}$.

Initially, a constant submaximal response of the tissue to a volume (x) of the extract of the standard dust was obtained. Then various volumes of the extract from the dust to be assayed (the unknown) were tested on the preparation until a volume (y) was found which produced a response equal to that elicited by the volume $(x)$ of the standard. The volumes $x$ and $y$ of standard and unknown respectively were each tested on the preparation a further three times $(x, y, x, y, x, y)$ to ensure that the responses were constant. These volumes of standard and unknown giving the same responses on the ileum contained equal amounts (that is, units) of the activity and from this the potency of the unknown was calculated. With this procedure the standard deviation of replicate assays on five different ileum preparations was $15 \%$ of the mean. For the results in the present experiment each assay was made on two ileum preparations and the figures expressed are the mean of the two values obtained.

The design of the assay was determined partly by the relatively small quantities of dust collected. In situations where larger amounts would be available, a more reliable approach would be to construct dose-response curves for each extract and determine the weight of dust which after extraction gives $50 \%$ of the maximal contraction.

\section{Chemical analysis}

Nitrogen was determined on total dust and dust extracts by the Kjeldahl procedure. For the dust extracts, total carbohydrate was estimated in terms of glucose by the anthrone method (Ashwell, 1957) and potassium, as potassium chloride, was estimated by flame photometry.

\section{Results}

Dust concentrations

Differences between the concentrations in the two

\begin{tabular}{|c|c|c|c|c|c|c|c|}
\hline \multirow{2}{*}{\multicolumn{2}{|c|}{ Mill }} & & \multirow{2}{*}{ Series } & \multicolumn{4}{|c|}{ Mean of dust concentration ${ }^{1}\left(\mathrm{mg} / \mathrm{m}^{3}\right)(S D)$} \\
\hline & & & & $<7 \cdot 1 \mu m$ & $<2 \mathrm{~mm}$ & $>2 \mathrm{~mm}$ & Total dust \\
\hline $\begin{array}{l}\text { Cotton } \\
\text { (Coarse) }\end{array}$ & $\begin{array}{l}\cdots \\
\cdots\end{array}$ & $\begin{array}{l}. . \\
.\end{array}$ & $\begin{array}{l}\text { A } \\
\text { B }\end{array}$ & $\begin{array}{l}0.61(0.14) \\
0.54(0.09)\end{array}$ & $\begin{array}{l}1.86(0.22) \\
0.82(0.13)\end{array}$ & $\begin{array}{l}3.93(0.58) \\
0.48(0.21)\end{array}$ & $\begin{array}{l}5.79(0.67) \\
1.30(0.25)\end{array}$ \\
\hline $\begin{array}{l}\text { Cotton } \\
\text { (Fine) }\end{array}$ & $\begin{array}{l}\cdots \\
\cdots\end{array}$ & $\begin{array}{l}\ldots \\
\ldots\end{array}$ & $\begin{array}{l}\text { A } \\
\text { B }\end{array}$ & $\begin{array}{l}0.73(0.08) \\
0.54(0.07)\end{array}$ & $\begin{array}{l}1.35(0.25) \\
1.51(0.39)\end{array}$ & $\begin{array}{l}2.23(0.35) \\
2.53(0.43)\end{array}$ & $\begin{array}{l}3.58(0.32) \\
4.05(0.51)\end{array}$ \\
\hline Flax & . & . & A & $3 \cdot 66(1 \cdot 67)$ & $11 \cdot 37(4 \cdot 37)$ & - & $11 \cdot 37(4 \cdot 37)$ \\
\hline Jute & . & . & A & $1 \cdot 62(0 \cdot 14)$ & $10 \cdot 98(1 \cdot 71)$ & $4 \cdot 35(1 \cdot 71)$ & $15 \cdot 33(1 \cdot 42)$ \\
\hline
\end{tabular}

${ }^{1}$ Each value is the mean of 5 samples

TABLE 1

Cotton, Flax and Jute Dust Concentrations 
cotton mills (Table 1) were found only in the size fractions larger than $7.1 \mu \mathrm{m}$; below this size the concentrations were essentially equal. Much higher concentrations were found in the flax and jute mills. At the jute mill, only a very small number of operatives were at risk at the sampling point. Comparison of the concentrations found in the coarse cotton mill in series A and series B indicates the efficiency of a dust suppression device that had been fitted in the intervening period; the total dust concentration had been reduced by some $80 \%$ but the reduction was associated only with the dust larger than $7.1 \mu \mathrm{m}$.

\section{Bioassay}

All the dust samples examined pharmacologically possessed smooth muscle contractor activity. The levels of activity for the dusts from each of the four mills are given in Table 2 where it may be seen that the dust from the coarse cotton mill is much more active than the others. Smooth muscle contractor activity in dusts from coarse cotton mills has also been found to be generally higher than that in dusts from mills processing medium grades of cotton (Berry et al., 1973). In series B, the investigation in the two cotton mills was repeated and extended to collect sufficient dust in the three size fractions to permit bioassay. The activity levels are given in Table 3 for the total dusts collected on this occasion and in Table $\mathbf{4}$ for the size selected samples. In this repeat investigation, the activity levels of the dusts from both mills were found to be much higher than on the first occasion. This may have been due to the change in dust standard employed for the assay. Since the stock of the Dutch cotton dust had been depleted, a sample of the dust collected in the first investigation was used as the standard in the second series. It is possible that this new standard may have lost some of its activity in the intervening period.
TABLE 3

Smooth Muscle Contractor Activity of Mill Dusts (Series B)

\begin{tabular}{|c|c|c|c|}
\hline \multirow{2}{*}{$\begin{array}{l}\text { Day of } \\
\text { collection }\end{array}$} & & \multicolumn{2}{|c|}{$\begin{array}{c}\text { Mean contractor activity }{ }^{1} \\
(\text { units } / g \text { dust })\end{array}$} \\
\hline & & Coarse cotton & Fine cotton \\
\hline $\begin{array}{l}\text { Monday } \\
\text { Tuesday .. } \\
\text { Wednesday.. } \\
\text { Thursday .. } \\
\text { Friday } \quad . .\end{array}$ & $\begin{array}{l}\ldots \\
\cdots \\
\cdots \\
\cdots \\
\cdots\end{array}$ & $\begin{array}{ll}21 & 420 \\
11330 \\
10200 \\
10200 \\
12370\end{array}$ & $\begin{array}{l}9180 \\
6089 \\
7140 \\
6800 \\
6089\end{array}$ \\
\hline Mean value & $\ldots$ & 13104 & 7060 \\
\hline
\end{tabular}

For this assay, the Thursday sample of cotton dust collected from the coarse mill (see Table 1) was employed as standard. The activity of this standard was 3400 units $/ g$

${ }^{1}$ Each value is the mean of two determinations

TABLE 4

Smooth Muscle Contractor Activity of Size SeParated Fractions of CotTon Dust

\begin{tabular}{cc|cc}
\hline \multirow{2}{*}{ Size fraction } & \multicolumn{2}{|c}{$\begin{array}{c}\text { Mean contractor activity } \\
\text { (Units } / g \text { dust) }\end{array}$} \\
\cline { 3 - 4 } & & Coarse cotton & Fine cotton \\
\hline$<7 \cdot 1 \mu \mathrm{m}$ &. & 11700 & 7200 \\
$<2 \mathrm{~mm}$ &. & 12800 & 6319 \\
$>2 \mathrm{~mm}$ &. & 4828 & 4540 \\
\hline
\end{tabular}

The standard cotton dust for the assay had a potency of 3400 units/g

${ }^{1}$ Each value is the mean of two determinations

TABLE 2

Smooth Muscle Contractor Activity of Mill Dusts (Series A)

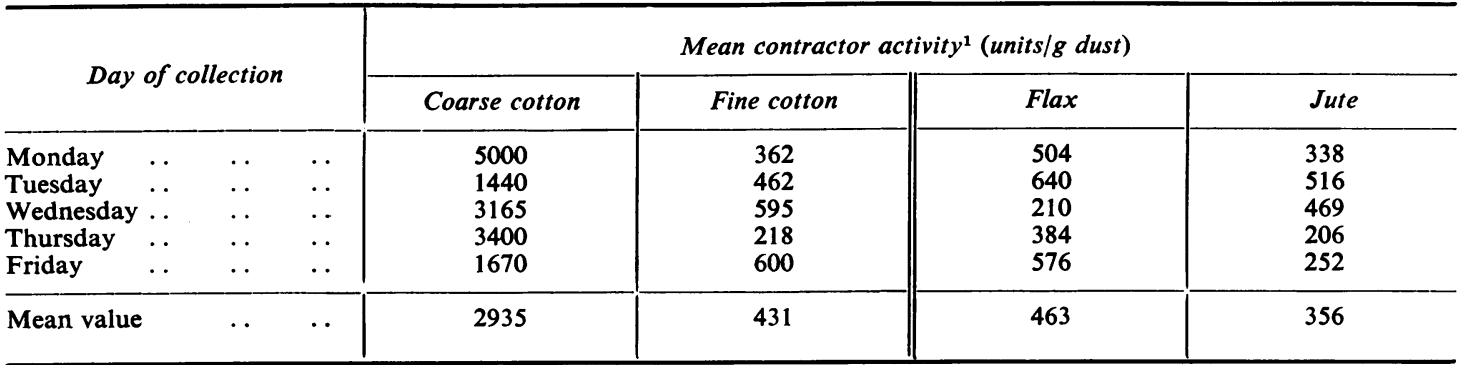

The smooth muscle contractor activity of the dust extracts was compared with that of standard extracts possessing a defined potency (as units of activity) on isolated guinea-pig ileum. For cotton dust, the standard was a sample of cotton dust from a Dutch mill with an assigned potency of 400 units/g; for jute and flax, the standard was a flax dust from a New Zealand flax mill assigned an activity of 200 units/g

${ }^{1}$ Each value is the mean of two determinations 
However, whatever the reasons for the changed levels of activity, it is the comparison between the cotton dusts from the two mills at each time which is of main interest. Thus it may be observed that on both occasions the activity of the coarse cotton mill dust was greater than that of the fine mill dust. The ratios of the mean activities (coarse: fine) are 7:1 for series $\mathrm{A}$ and $2: 1$ for series $\mathrm{B}$. These are of a similar order to the ratio for the prevalence of byssinosis in these two mills, namely, 3:1 (Roach and Schilling, 1960).

Of the three size selected fractions, it is the largest sized fraction that possesses the lowest level of activity for both the coarse and fine samples. As dust suppression in the coarse cotton mill reduced the dust fraction above $7 \cdot 1 \mu \mathrm{m}$ an increase, if anything, in the activity ratio of coarse: fine mill dust was to have been expected. The observed reduced ratio between the two dusts in series B may, therefore, be due to some change in conditions at a point in processing prior to carding.

The variation of the smooth muscle contractor activity between days was greater in series A. Some of this variation may have been due to 'sampling' of the $1 \mathrm{~g}$ of dust required for assay from the total dust collected on each day. In series B the whole of the dust collected on each day was used for the assay. It is interesting to note that in both series the level of the activity in the Monday samples from the coarse cotton mill was greater than that on other days. Whether this has any relation to Monday symptoms is, of course, purely speculative.

The activity of an extract prepared from a sample collected in the coarse cotton mill was reduced by $19 \%$ after filtration through a micropore cellulose membrane. The material retained by the filter was scraped off and resuspended in a volume of Tyrode solution equivalent to the original extract. This suspension produced a small contraction of the isolated guinea-pig ileum.

The contractor activity of flax and jute dust extracts was of a similar order to that found in the fine cotton samples (Table 2). The type of contractile response to the ileum produced by jute is different (slower in onset) from that elicited by cotton dust (Davenport and Paton, 1962) and the observations of the present investigation (see Methods section) indicates that the contractor activity of flax is different in nature from that in cotton dust. In addition, it is possible that the active substance in jute is not the same as that in flax. Therefore, the quantitative comparison of these two dusts is not very reliable. As size selected samples of these dusts were not collected, the activity of dust in the different size respirable ranges in unknown.

\section{Chemical analysis}

The results of the chemical determinations on the cotton dust samples (series A) are presented in Tables 5 and 6. There is no obvious trend of composition with day of the week and in certain instances there was a marked variation between samples collected simultaneously. The variation was greatest in the dust from the coarse cotton mill and may be associated with the sampling error previously referred to. The dust samples from this mill were much darker in colour than those from the fine cotton mill. This was taken as indicating that the dark dust contained a higher proportion of pigmented plant debris. However, although on average the analyses suggest that there are real differences in the chemical composition of the two cotton dusts, it is the dust from the fine cotton mill that contains more per $g$ of each constituent determined. No correlation of the contractor activity with any of these chemical constituents was found (Table 7).

TABLE 5

Chemical Analysis of Cotton Dust (Series A: Coarse Cotton)

\begin{tabular}{|c|c|c|c|c|c|c|}
\hline \multicolumn{2}{|c|}{ Day of collection } & $\begin{array}{c}\text { Soluble potassium } \\
\qquad(\mathrm{mg})\end{array}$ & $\begin{array}{c}\text { Total nitrogen } \\
(\mathrm{mg})\end{array}$ & $\begin{array}{c}\text { Soluble nitrogen } \\
(\mathrm{mg})\end{array}$ & $\begin{array}{c}\text { Soluble } \\
\text { carbohydrate } \\
(\mathrm{mg})\end{array}$ & $\begin{array}{c}\text { Contractor } \\
\text { activity } \\
\text { (units) }\end{array}$ \\
\hline $\begin{array}{l}\text { Monday } \\
\text { Tuesday } \\
\text { Wednesday } \\
\text { Thursday } \\
\text { Friday . . }\end{array}$ & $\begin{array}{l}\cdots \\
\cdots \\
\cdots \\
\cdots \\
\cdots\end{array}$ & $\begin{array}{l}2 \cdot 163 \\
1 \cdot 699 \\
3 \cdot 545 \\
1.661 \\
1 \cdot 728\end{array}$ & $\begin{array}{r}10 \cdot 77 \\
7 \cdot 84 \\
11 \cdot 46 \\
10 \cdot 87 \\
12 \cdot 26\end{array}$ & $\begin{array}{l}1.006 \\
0.835 \\
1.041 \\
0.945 \\
0.757\end{array}$ & $\begin{array}{r}19 \cdot 10 \\
11 \cdot 68 \\
16 \cdot 18 \\
9 \cdot 05 \\
14 \cdot 56\end{array}$ & $\begin{array}{l}5000 \\
1440 \\
3115 \\
3400 \\
1670\end{array}$ \\
\hline Mean value & . & $2 \cdot 154$ & $10 \cdot 65$ & 0.9167 & $14 \cdot 12$ & 2935 \\
\hline
\end{tabular}

All values are expressed / $\mathrm{g}$ of dust and represent the means of two determinations

Potassium, determined by flame photometry, is expressed as potassium chloride

Nitrogen was determined by the Kjeldahl method

Carbohydrate, determined by the anthrone reaction, is expressed as glucose 
TABLE 6

Chemical Analysis of Cotton Dust (Series A: Fine Cotton)

\begin{tabular}{|c|c|c|c|c|c|c|}
\hline \multicolumn{2}{|c|}{ Day of collection } & $\begin{array}{c}\text { Soluble potassium } \\
\text { (mg) }\end{array}$ & $\begin{array}{c}\text { Total nitrogen } \\
(\mathrm{mg})\end{array}$ & $\begin{array}{c}\text { Soluble nitrogen } \\
(m g)\end{array}$ & $\begin{array}{c}\text { Soluble } \\
\text { carbohydrate } \\
\text { (mg) }\end{array}$ & $\begin{array}{c}\text { Contractor } \\
\text { activity } \\
\text { (units) }\end{array}$ \\
\hline $\begin{array}{l}\text { Monday } \\
\text { Tuesday } \\
\text { Wednesday } \\
\text { Thursday } \\
\text { Friday .. }\end{array}$ & $\begin{array}{l}\cdots \\
\cdots \\
\cdots \\
\cdots\end{array}$ & $\begin{array}{l}7 \cdot 713 \\
2 \cdot 740 \\
2 \cdot 997 \\
2 \cdot 413 \\
3 \cdot 221\end{array}$ & $\begin{array}{l}11 \cdot 49 \\
12 \cdot 46 \\
14.64 \\
13 \cdot 01 \\
12.00\end{array}$ & $\begin{array}{l}1 \cdot 123 \\
0 \cdot 781 \\
0.911 \\
1.026 \\
0 \cdot 550\end{array}$ & $\begin{array}{r}18 \cdot 23 \\
9 \cdot 93 \\
14 \cdot 05 \\
28 \cdot 58 \\
36 \cdot 31\end{array}$ & $\begin{array}{l}362 \\
463 \\
595 \\
218 \\
600\end{array}$ \\
\hline Mean value & . & 3.916 & $12 \cdot 72$ & 0.8793 & $21 \cdot 42$ & 448 \\
\hline
\end{tabular}

All values are expressed / $\mathrm{g}$ of dust and represent the means of two determinations

Potassium, determined by flame photometry, is expressed as potassium chloride

Nitrogen was determined by the Kjeldahl method

Carbohydrate, determined by the anthrone reaction, is expressed as glucose

TABLE 7

Correlation Coefficients between Smooth Muscle Contractor Activity and Chemical CONSTITUENTS OF COTTON DUST

\begin{tabular}{lll|c|c|c|c}
\hline \multicolumn{2}{c|}{ Dust } & & Potassium & Total nitrogen & Soluble nitrogen & Carbohydrate \\
\hline Coarse cotton & $\ldots$ & $\ldots$ & +0.2949 & +0.2815 & +0.8006 & +0.5091 \\
Fine cotton .. &.. &. & -0.2566 & +0.2654 & -0.7011 & -0.0526 \\
\hline
\end{tabular}

\section{Discussion}

While it is clear that the dusts from the mill with a high prevalence of byssinosis possessed a greater amount of smooth muscle contractor activity than those from the mill with a low prevalence, it is less clear how this activity is related to the symptoms of the disease. It has been assumed that the substance contracting the ileum is responsible for the contraction of animal and human bronchial muscle seen in vitro with cotton dust extracts (Davenport and Paton, 1962; Nicholls, 1962). As seen from the sizeseparated fractions, the fine dust is active and this suggests that the contractor substance is able to reach the finer branches of the bronchial tree where it could cause bronchoconstriction. The amounts of dust required to produce effects on the isolated ileum and bronchi are of the order of $100 \mathrm{mg}$ and even larger quantities are necessary to elicit the other pharmacological actions that have been observed (Antweiler, 1960; Davenport and Paton, 1962; Nicholls, 1962; Bouhuys, 1963a). However, it would take several weeks for a cardroom worker to inhale quantities such as these. Using doses which approximate more closely to the situation in the mills, Bouhuys and Nicholls (1966) have failed to observe any change in the airways resistance and pulmonary compliance of unanaesthetized guinea- pigs when these animals were exposed to aerosols of extracts of cotton dust. This demonstrates that, in the guinea-pig, the smooth muscle contractor agent is unable to cause any acute byssinosis-like changes in pulmonary function. It is not known whether this is true in man as species differences in sensitivity to the contractor agent may exist. As the acute symptoms of byssinosis appear to be associated largely with a release of histamine in the lungs (Edwards et al., 1970), then if the smooth muscle contractor is active in man, it must play only a relatively small role in this phase of the disease. However, this direct-acting contractor substance may be involved in the pathogenesis of the chronic stages of the disease. The active substance may be regarded as a noxious stimulus and regular inhalation of the dust may thus represent repeated micro-insults to the respiratory tract with consequent chronic sequelae. Thus assay of the smooth muscle contractor agent may provide an index of relevant dust activity.

Although on the basis of the bioassay, the comparison between the two cotton dusts reflected the relative prevalence of byssinosis in the respective mills, the bio-activity does not appear to be a reliable guide to assessing the hazard of exposure to such a dust in view of the uncertain role of this activity in producing the symptoms of byssinosis. In addition, as has been indicated earlier, the comparison with 
the other vegetable dusts is not reliable. Even if it were, the assay results have not discriminated between the fine cotton dust, flax, and jute although the prevalence of byssinosis differed considerably in the respective mills using these fibres.

It is possible that, while in cotton and flax dusts the contractor activity with a quick onset of action on the ileum is associated with the production of the byssinotic state, the slow contractor activity of jute contributes only to the decrease of FEV $_{1.0}$ seen in jute workers (Valić and Žuškin, 1971).

The results of the present experiments give no clue to the chemical nature of the contractor substance which still remains unidentified. Absence of correlation of activity with nitrogen or carbohydrate indicates that either the active substance is present only in small amounts and is overlooked because of the large amounts of inactive material or that the correct chemical determination has not been made. Davenport and Paton (1962) have suggested that the contractor activity may be associated with the presence of charged particles in the dust extracts. If this were substantiated, a simple relation of activity to a chemical constituent would not be expected. From the results of membrane filtration of the cotton dust extract, it is evident that a proportion of the smooth muscle contractor activity is associated with particulate matter. Such a pharmacological effect of particles may explain why aqueous extracts prepared from synthetic fibre dusts possess smooth muscle contractor activity (Berry et al., 1973).

Several other proposals as to the nature of the smooth muscle contractor agent in cotton dust have been made, namely, an amphoteric substance of unknown structure (Davenport and Paton, 1962) and a polysaccharide complex (Nicholls, 1962). With reference to the latter suggestion, we have recently found that an aminopolysaccharide fraction, byssinosan, prepared from cotton dust by the method of Mohammed, El-Gazzar, and Adamyova (1971), is capable of contracting the isolated guineapig ileum in the presence of atropine and mepyramine. Antweiler (unpublished work presented at the first International Conference on Byssinosis, Manchester, 1962) suggested that various amino acid-like compounds in cotton dust contracted smooth muscle. The amino acids, serine, alanine, glycine, and proline produce a contraction of guinea-pig ileum in the presence of mepyramine (Lewis et al., 1972). These free amino acids have been found in the dormant and germinating cotton seed (Lloyd and Nicholls, 1965) and it is possible that they are present in cotton dust. However, it is doubtful that their concentration is sufficiently high to elicit a response on the isolated ileum.

The complete chemical characterization of this active agent would appear to be an essential prerequisite of any further studies in animals and man of the possible role of the smooth muscle contractor activity in the acute and chronic phases of byssinosis. Until this occurs, the empirical correlation reported here between smooth muscle contractor activity and the prevalence of byssinosis in two cotton mills is of limited value. Only when a causal connexion has been established between chronic inhalation of such an active agent and byssinosis would a bioassay technique be useful for the assessment of the byssinogenic potency of various dusts. Such a study extended to the other vegetable fibre dusts may also be of value in explaining respiratory effects after their inhalation (Valić and Žuškin, 1971).

P J N thanks the Medical Research Council for financial assistance.

\section{References}

Antweiler, H. (1960). Tierexperimentelle Untersuchungen zur Pathogenese der Byssinosis. Archiv für Gewerbepathologie und Gewerbehygiene, 17, 574-588.

- (1961). Histamine liberation by cotton dust extracts: evidence against its causation by bacterial endotoxins. British Journal of Industrial Medicine, 18, $130-132$.

Ashwell, G. (1957). In Methods in Enzymology, Vol. 3, p. 84, edited by S. P. Colowick and N. O. Kaplan. Academic Press, New York.

Berry, G., McKerrow, C. B., Molyneux, M. K. B., Rossiter, C. E., and Tombleson, J. B. L. (1973). A study of the acute and chronic changes in ventilatory capacity of workers in Lancashire cotton mills. British Journal of Industrial Medicine, 30, 25-36.

Bouhuys, A. (1963a). Byssinosis in a cotton weaving mill. Archives of Environmental Health, 6, 465-468.

(1963b). Prevention of Monday dyspnoea in byssinosis: controlled trial with an antihistamine drug. Clinical Pharmacology and Therapeutics, 4, 311-314.

_ and Nicholls, P. J. (1966). The effect of cotton dust on respiratory mechanics in man and in guinea-pigs. In Inhaled Particles and Vapours II: Proceedings of an International Symposium: Cambridge 1965 , pp. $75-85$, edited by C. N. Davies. Pergamon, Oxford.

—, Van Duyn, J., and Van Lennep, H. J. (1961). Byssinosis in flax workers. Archives of Environmental Health, 3, 499-509.

Braun, D. C., Scheel, L. D., Tuma, J., and Parker, L. (1973). Physiological response to enzymes in cotton dust: a preliminary report. Journal of Occupational Medicine, 15, 241-244.

Cavagna, G., Foa, V., and Vigliani, E. C. (1969). Effects in man and rabbits of inhalation of cotton dust or extracts and purified endotoxins. British Journal of Industrial Medicine, 26, 314-321.

Davenport, A. and Paton, W. D. M. (1962). The pharmacological activity of extracts of cotton dust. British Journal of Industrial Medicine, 19, 19-32.

Edwards, J. H. and Jones, B. M. (1974). Immunology of byssinosis: the study of the reaction between the 
isolated byssinosis 'antigen' and human immunoglobulins. Annals of the New York Academy of Science, 221, 59-63.

, McCarthy, P., McDermott, M., Nicholls, P. J., and Skidmore, J. W. (1970). The acute physiological, pharmacological and immunological effects of cotton dust in normal subjects. Journal of Physiology, 208, 63P.

Elwood, P. C. (1965). Respiratory symptoms in men who had previously worked in a flax mill in Northern Ireland. British Journal of Industrial Medicine, 22, 38-42.

—, Pemberton, J., Merrett, J. D., Carey, G. C. R., and McAulay, I. R. (1965). Byssinosis and other respiratory symptoms in flax workers in Northern Ireland. British Journal of Industrial Medicine, 22, 27-37.

Lewis, G. P., McMartin, M., Rosenthal, S. R., and Yates, C. (1972). Isolation and identification of pharmacologically active amino acids in skin and their structure-activity relationship on the guinea-pig ileum. British Journal of Pharmacology, 45, 104-117.

Lloyd, G. R. and Nicholls, P. J. (1965). Formation of histamine in the cotton plant. Nature, 206, 298.

Mair, A., Smith, D. H., Wilson, W. A., and Lockhart, W. (1960). Dust diseases in Dundee textile workers. British Journal of Industrial Medicine, 17, 272-278.

Massoud, A. and Taylor, G. (1964). Byssinosis: antibody to cotton antigens in normal subjects and in cotton cardroom workers. Lancet, 2, 607-610.

McKerrow, C. B., McDermott, M., Gilson, J. C., and Schilling, R. S. F. (1958). Respiratory function during the day in cotton workers: a study in byssinosis. British Journal of Industrial Medicine, 15, 75-83.

Mohammed, Y. S., El-Gazzar, R. M., and Adamyova, K. (1971). Byssinosan, an aminopolysaccharide isolated from cotton dust. Carbohydrate Research, 20, 431-435.

Nicholls, P. J. (1962). Some pharmacological actions of cotton dust and other vegetable dusts. British Journal of Industrial Medicine, 19, 33-41.

_- Nicholls, G. R., and Bouhuys, A. (1966). Histamine release by compound $48 / 80$ and textile dusts from lung tissue in vitro. In Inhaled Particles and Vapours, II: Proceedings of an International Symposium, Cambridge, 1965, pp. 69-74, edited by C. N. Davies. Pergamon, Oxford.

Pernis, B., Vigliani, E. C., Cavagna, C., and Finulli, M. (1961). The role of bacterial endotoxins in occupational diseases caused by inhaling vegetable dusts. British Journal of Industrial Medicine, 18, 120-129.

Roach, S. A. and Schilling, R. S. F. (1960). A clinical and environmental study of byssinosis in the Lancashire cotton industry. British Journal of Industrial Medicine, 17, 1-9.

Schilling, R. S. F. (1956). Byssinosis in cotton and other textile workers. Lancet, 2, 261-265, 319-324.

—_, Vigliani, E. C., Lammers, B., Valić, F., and Gilson, J. C. (1964). A report on a conference on Byssinosis. In Proceedings of the XIV International Congress of Occupational Health, Madrid, 1963, vol. 2, pp. 137-145. Excerpta Medica, Amsterdam.

Valić, F. and Žuškin, E. (1971). A comparative study of respiratory function in female non-smoking cotton and jute workers. British Journal of Industrial Medicine 28, 364-368.

Received for publication 19 May 1975

Accepted for publication 23 July 1975 